\title{
The English Armada: the greatest naval disaster in English history
}

Review Number: 2312

Publish date: Thursday, 14 March, 2019

Author: Luis Gorrochategui Santos

ISBN: 9781350016972

Date of Publication: 2018

Price: $£ 80.00$

Pages: 336pp.

Publisher: Bloomsbury Academic

Publisher url: https://www.bloomsbury.com/uk/the-english-armada-9781350016972/

Place of Publication: London

Reviewer: Manuel del Campo

Gorrochategui's book is a revised and updated translation of the Spanish edition (Spanish Ministry of Defence, 2011). It sheds new light on an obscure, but fundamental, episode of the undeclared Anglo-Spanish War (1585-1604) that took place a year after the Spanish Armada. Interestingly, although Queen Elizabeth I was at first intentionally misinformed about this, once she knew the grim reality, she silenced it. The Queen prohibited any publication about the English Armada (also known as the Counter-Armada or Drake-Norris expedition) trying, successfully, to hide the disastrous result suffered by the English in that military campaign on the Iberian mainland. Only a few propaganda pamphlets were published in order to hide the truth, treating real but unfavorable facts as false rumors and instead showing a false aftermath of the campaign favorable to the English. According to the author, these pamphlets - the first by Anthony Wingfield (1) - were taken for reliable sources by British historians.

Gorrochategui's thesis is that little attention has been paid to the Counter-Armada by historians, particularly in the English-speaking world. The author contrasts this fact with the vast literature produced on the Spanish Armada. There are a few exceptions: for instance, the British Hispanist Martin A. S. Hume (2) dedicated a full chapter to the Counter-Armada in his work The year after the Armada (1896). Hume was the first to proclaim the importance of that campaign previously consigned to oblivion:

'The story of this ill-starred expedition is usually disposed of in a few lines by English historians, although it success would have completely changed the status of England on the Continent'.

Gorrochategui goes further: he thinks that with Portugal under English control, it would have opened new horizons for England in the Americas, considering Portuguese territories overseas. It is also worth pointing out the good job done by R. B. Wernham (3) in gathering the English sources of the Drake-Norris expedition in a single volume.

Furthermore, the English Armada episode becomes crucial when considering that British historiography used - particularly in the Victorian era - the failure of the previous Spanish Armada to build a national myth around it. Historical facts were transformed into a self-interested version describing a sort of knock-out blow 
to the Spanish Empire far from the reality of the situation. In addition, the author wonders himself how these two similar episodes, two great naval disasters, could have received such differing historical attention. Both involved more than 20,000 men and more than 100 ships, with clearly fewer ships on the Spanish side, as theirs were on average larger than those of the English. The English sources for the Counter-Armada are less accurate, and according to the author, the calculations of the number of men embarked were approximate. In a single document there are two contradictory figures stating the total of men: 23,375 and 27,667. The second of these, written in a postscript signed by both Drake and Norris is considered by Gorrochategui to be the correct one. However, some historians such as Agusti?n Rodríguez González believe that the first number is the one closer to reality.(4) Anyway, both Spanish and English Armadas were naval catastrophes of a similar size.

The book is based on numerous primary sources from different libraries and archives (some previously unused for research in this area), particularly the Spanish National Library and the Simancas Archives, and reconstructs the campaign on a daily basis, thanks largely to the great detail given by the Iberian manuscript sources. The author mainly uses the English primary sources compiled by Wernham. The bibliography covers both Spanish and English Armadas, as well as Spanish and Elizabethan warfare, the latter in less detail.

The work is divided into three sections. Firstly, the author gives an introductory account of the previous episode of the Spanish Armada and how this was distorted. Gorrochategui argues that this was not a defeat, but rather a frustrated attack, which had its cause more in a Spanish failure due mainly to bad tactics, than in English merit. In fact, the Spanish fleet was dispersed due to unfavorable weather conditions and could only partially go into combat. Its original goal was to arrive in Flanders to meet the fleet of the Duke of Parma, and only then to jointly attack England. In addition, the Spanish fleet reached Flanders suffering little damage. It was in the battle of Gravelines that the fleet registered a few withstandable losses. Unfortunately, the lack of records on the English side makes a fair comparison impossible, but many English ships were not seen again after that day, and the English avoided further combats. Moreover, it was on the way round to the British Isles, in order to return home, that the Spanish ships suffered the most, when no English ships were present. Finally, the English fleet repeatedly avoided a bigger battle on the open sea. Antonio Luis Gómez Beltrán (5) reminds us to take into account the nature of the English ships; despite being more numerous, they were smaller in average, and thus did not approach the Spanish ships at close quarters, maintaining a large distance between their ships. Ultimately, the Spanish failure implied a victory for the English; but not a decisive one, especially considering the rebalancing that came afterwards with the Drake-Norris expedition.

The book goes on to detail the aim of this expedition. First, Queen Elizabeth I could not afford a fleet similar in size to the previous Spanish one. However, she needed to react quickly, so she financed a small part of the fleet, relying for the rest of the funding on private investment. She commissioned both Sir Francis Drake and Sir John Norris to command the expedition, the first in charge of the fleet, and the second of the army troops. Little did she know that her orders to go to Santander to destroy the Spanish fleet then under repair would be ignored, as Drake, a knight of the realm, but also a privateer of long-standing, altered the original plan thinking that attacking the city of Corunna could be more lucrative - an action that obviously infuriated the Queen afterwards.

Dom Anto?nio, the Prior of Crato (1531-95), had conspired against Philip II of Spain (and Philip I of Portugal) to take the Portuguese throne by force. After the Portuguese War of Succession, he looked to have lost any chance of achieving this, especially as he was illegitimate. Crato therefore saw in the CounterArmada a last chance. It is worth mentioning that the agreement between England and Dom Anto?nio, (included in the book) was extremely one-sided, and would have forced Portugal to pay annually huge sums of money to the Queen of England. Dom Anto?nio was selfish enough to sign it, disregarding the onerous consequences that it would have had for his country if the Drake-Norris expedition had been successful.

The second section, covering the actual Corunna and Lisbon attacks, forms the core of the book. These chapters are conveniently illustrated with maps and other additional materials, with the former including 
brief bullet points which are particularly useful in summarizing some episodes.

It is necessary at this stage to describe briefly what occurred during the expedition.

The fleet arrived in the bay of Corunna on 4 May 1589 and left on 19 May. The attack mainly took place on land, because the town was well protected along the coastline. Most of the Spanish forces were on the walls of the isthmus that gives access to the peninsula where the city lies. Once this barrier was breached by the English, there was a good chance that the siege would be successful, but in the end it failed. One of the most important episodes was the siege of the higher part of the city. It was defended by a mixture of Spanish troops and militia, including women who played an important role in the last stages of the combat. One of them, María Pita, showed her bravery by killing a standard-bearer who was trying to reach the top of the wall. This unusual incident involving a female protagonist was noticed by many and reflected in the war accounts, María Pita becoming a local heroine ever since. Eventually, the English decided to abandon the siege and left Corunna, but it took time and the loss of further lives for them to reach their ships and embark.

In summary, in this first attempt, the English unsuccessfully besieged a town of 4,000 people, losing 1,300 men. According to Gorrochategui, this was an unexpected defeat that affected the troops' confidence. Furthermore, they had still not attacked the much bigger city of Lisbon, one of the main targets of the expedition.

Once again, the joint command of the fleet between Norris and Drake led to differences that contributed to the failure of the mission. Drake wanted to directly attack Lisbon by way of the Tagus estuary, taking advantage of favourable winds and tide; while Norris wanted to disembark in Peniche, around $80 \mathrm{~km}$ away from Lisbon. They chose the latter, landing on a nearby beach on 25 May. It was the wrong choice, especially considering they were poorly equipped for a land invasion, being without the necessary animals and wheeled vehicles, which made their advance hard and slow. They were also counting on Portuguese supporters of Dom António's cause joining, which they did not.

Drake's fleet continued down to Cascais, where he waited at sea for the arrival of the rest of the expedition. Drake had enough soldiers to attack, but he simply waited passively, focusing only in raiding cargo boats passing through that area. He was later accused of cowardice by Norris, Dom Anto?nio and other expeditionaries. The Spanish had the advantage of cavalry, who harassed Norris' troops the whole way down to Lisbon. The aim was to weaken them, by making it hard for them to find enough food supplies. Thus, the English arrived in Lisbon in bad condition, and partially in poor health.

The Spanish-Portuguese plan was that the core of the army should stay and defend Lisbon. The Iberian coalition knew that Drake and his fleet were next to the city, so they avoided a major battle outside its walls. That would have left them in a weak position, as if both English armies had attacked them simultaneously in the Spanish troops absence, the city would had been defenceless. Incidentally, in Lisbon 5,000 Spanish veteran infantry soldiers (the reputed Tercio companies) were ready for war, among other troops, while in Corunna there were only 500 veterans among the army men.

After some skirmishes in Lisbon, the English were attacked in their camp (in the Bica neighbourhood), on three different fronts on 3 June, which proved decisive. The following day, they escaped during the night leaving wood fires to distract the Spanish. However, they were discovered, so had to hurry and suffered new attacks by the Spanish cavalry. After that, the only concern for the Iberian troops was the possibility of a naval attack that never happened. They pursued the English, harassing them up as far as Cascais. Eventually, the English embarked on 15 June, but were followed by Iberian troops as well as the Spanish galleys that sank several of their enemy ships.

The return voyage was full of problems, with adverse sea conditions that lengthened their journey (the same thing happened to the Spanish Armada) and many lives being lost to illness. They were forced to stop urgently in Vigo, razing the nearly abandoned town. They also faced opposition there, resulting in further 
loss of troops.

In summary, the campaign was marked from the beginning by the failure to follow Elizabeth's order to attack the damaged Spanish fleet, docked mainly in Santander for repair. The dual command was a big mistake that led to poor decision-making, and the failure to achieve any of their goals. Once they were back in England there was a serious disagreement between Drake and Norris, who tried to blame each other. Both were privately punished. The casualties were far greater than with the Spanish Armada. Only 102 ships returned to England with 3,722 men who claimed their pay. Hume states a maximum of 5,000 survivors. Gorrochategui gives a figure of 20,000 men lost, a number considerably superior that of the Spanish Armada (11,000 in the campaign, excluding another 2,000 men who died due to plague in Lisbon before the expedition set off).

The last chapters of the book cover what happened in the following years. It is worth pointing out that after the Counter-Armada, Drake did not receive any commissions from the Queen for some years, until 1595 when he suffered another big defeat while attacking the Spanish territories in America. He then died of dysentery in Portobello, just after the unfruitful attack to San Juan on Puerto Rico. In addition, the AngloSpanish War ended with both sides seeking peace in order to stop the costly conflict. However, the treaty validated the previous status quo, favorable to Spain in that it completely preserved its empire - whilst not allowing any English attack against Spanish America. England also had to stop supporting the Dutch rebellion against Spanish rule.

In his epilogue Gorrochategui defends the Spanish contributions to navigation in 16th century, explaining how influential some Spanish early treatises on the matter were, and giving an example with many English editions. It is worth recalling that both the Spanish and the Portuguese took navigation further in the 15th and 16th centuries, contributing greatly to the Age of Discoveries. In addition, he revises mistakes in the historiography on both Armadas as well as some of the distortions of these campaigns and makes the point that in this respect historians have often been self-congratulatory.

It is worth noting however that a revision of the historiography was undertaken around the 400th anniversary of the Spanish Armada, putting into question old assumptions which considered this a crucial and complete victory. Recent contributions such as this one, or for instance works by Rodríguez Gonza?lez or the complete text by Go?mez Beltra?n have added new insights and helped further challenge old myths.

A hot topic of debate in Spanish Armada historiography has been the comparison between English and Spanish artillery. Go?mez Beltra?n's work includes a valuable and comprehensive study of Spanish artillery. The lack of standardisation, combined with the varied terminology used in the different sources presents a problem. Rodríguez González argues in a recent book that the lack of sources on the English side make this comparison impossible, referencing earlier previous inaccurate works in English on the subject (from Julian Corbett to Geoffrey Parker). Despite this lack of information that makes any definitive statement problematic he is inclined to think that both naval gunneries were not that different. Although Spanish gunnery was superior, its effectiveness could not be proved due to the long distance shooting employed by the English in the Spanish Armada, and due to the circumstances of the battle of Gravelines.

In conclusion, this monograph dedicated to the Counter-Armada is the first to give a full account of the expedition, and represents an eye-opening contribution to the study of the Anglo-Spanish War (1585-1604) historiography. Despite what one may assume from numerous earlier books, this war did not end well for the English. As a result, after the Drake-Norris expedition, the war was rebalanced in favour of the Spanish. In addition, Spain as a global empire could endure such losses more easily than the much weaker Elizabethan England. Although in this war there was not a definitive victory that resulted in a clear winner, it is very revealing that the peace treaty returned to the status quo ante bellum that was favorable to Spain and its empire. 


\section{Notes}

1. Anthony Wingfield, A trve coppie of a discourse written by a gentlemen employed in the late voyage of Spaine and Portingale... (London, 1589; available in facsimile ed.). Back to (1)

2. Martin A. S. Hume, The year after the Armada (London, 1896).Back to (2)

3. The expedition of Sir John Norris and Sir Francis Drake to Spain and Portugal, 1589, ed. R. B. Wernham (London, 1988).Back to (3)

4. Agustín R. Rodríguez González, Drake y la 'Invencible': mitos desvelados (Madrid, 2011); Ibid., El león contra la jauría: batallas y campañas navales españolas 1621-1640 (Málaga, 2018). Back to (4)

5. Antonio Luis Gómez Beltrán, La invencible y su leyenda negra (Málaga, 2013).Back to (5)

Source URL:https://reviews.history.ac.uk/review/2312

\section{Links}

[1] https://reviews.history.ac.uk/item/301985 